\title{
Gene expression profile of four immune genes in AIDS patients
}

Received : 7/12/2017

Accepted : 18/1/2018

\author{
Abdulrhem T. Al-Ghazal. \\ Department of Biology, College of Science, University of Mosul, Mosul, IRAQ \\ Postal code: 11942, P.O.BOX: 13739, Phone: (00964)07704139591 \\ Fax: 0096265356746 , bakurius@yahoo.com
}

\begin{abstract}
Human immunodeficiency virus (HIV) is one of Retroviruses which cause acquired immunodeficiency syndrome (AIDS) associated with severe effect on immune system. Retroviruses possess a reverse transcriptase (RT) enzyme that convert viral RNA template into DNA which integrates with cellular DNA to cause persistent infection. The relationship between HIV and the immune system has also yielded important insights into mechanisms of immune homeostasis and host defenses in general. HIV causes impact on expression of immune genes. Four immune genes were subjected to this study using analysis of Bioinformatics tools represented by Real-time-reverse transcription PCRarray (RT-PCR-array) (SABioscience). Control genes were taken from previous studies to get the fold change of gene expression. The results showed that all subjected genes were up regulated with different fold change for each one (IFNA2, 11.2713 fold; IL10, 103.5786 fold; IL10RA2, 12.0803 fold; CXCL8, 34.1682 fold). These results may give important information to comprehend the relationship between HIV and human immune cells.
\end{abstract}




\section{Introduction}

Human immunodeficiency virus is an RNA virus belongs to genus lentivirus within the family Retroviridae. It affect immune cells especially the innate immunity. Response to viruses requires their early detection through pathogen recognition receptors and the recruitment of the efficient antiviral response that is centered on the release of type 1 interferon (See and Wark, 2008).Human immune deficiency virus (HIV) is chosen for this study to investigate its effect on human immune gene expression (up-regulated and downregulated genes which provide insights into functional responses of both host and pathogen (Penelope, et al., 2004).

Most previous studies have emphasized on the epidemiological aspects of HIV infections and only few studies have examined the effect of viral infections on human gene expression using advanced techniques. Expression microarray analysis is a powerful method to determine global profiles of gene in cells and tissues under a variety of complex biological conditions (Clewley, 2004). Most of recent medical and scientific debates have concentrated on: how some HIV infections develop into immune sensitivity, if this correlation occurs what are the molecular changes that take place at the gene level, which genes will be up-regulated or downregulated that may lead to immune sensitivity, which virus will be the most effective to stimulate such genes, what is the interpretation for these complications and if there is a possibility to treat these cases at the molecular gene level. (Simpson et al.,2006).

Cytokines are signaling molecules that are used in cellular communication. They are proteins (glycoproteins) produced widely throughout the body by cells of diverse embryological origin (Khatri et al., 2010). Cytokines play a key role in the development and functioning of both the innate and adaptive immune response. They are often secreted by immune cells that have encountered a pathogen such as viruses, thereby activating and recruiting immune cells to increase the system's response to the pathogen (David et al., 2008).

In this study RT-PCR-Array technique was chosen for a number of reasons. First, little is known about the immune cells genomic response to infections with HIV virus. Second, only microarrays and RT-PCR-Arrays could definitely determine whether the immune cell-viral infections will be accompanied by a particular pattern of change in gene expression. Third, it would be necessary to have data on immune cell's gene regulation (Myskiw et al., 2009).

The aims of this study are; to detect the effect of HIV infection on the mRNA expression of four cytokines: Interferon, alpha 2 (IFNA2), Interleukin 10 (IL0), Interleukin 10 receptor, alpha (IL10RA), and chemokine (C-X-C motif) ligand 8 (CXCL8).This study may lead to 
increase the knowledge of relationship between human inflammatory gene expression and HIV.

\section{Materials and Methods}

\section{Blood samples (Control)}

Ninety patients hospitalized at Ibn ALHaytham Hospital in Amman/Jordan for viral infections are included to analyze their gene expression changes in their leukocytes. EDTA-blood (5ml) was collected from 90 patients after complete recovery from viral infection and used as control samples and compared with acute infection with HIV sample from previous researches.

\section{Extraction of mRNA from controls leukocyte}

The RNA is extracted within $24 \mathrm{~h}$ of blood collection as follows: RNAextraction phase, treat the leukocytes that isolated from the blood Buffy coat after 30 days of recovery from viral respiratory infections (used as Control) with Trizol reagent (Phenol-guanidinisothiocyanate) (Invitrogen).

\section{RNA quantitation}

Spectrophotometer (Bio-Rad-USA) analysis is carried out to determine the concentration $(\mu \mathrm{g} / \mathrm{ml})$ of RNA by measuring the optical density (O.D) at $\lambda 260$ and according to the following equation: RNA concentration $=40$ (O.D factor) $\mathrm{x} 25$ (dilution factor) $\mathrm{x}$ O.D at 2260. RNA quality is tested using two methods, spectrophotometer (Bio-Rad) and gel-electrophoresis. In spectrophotometer the O.D260/280 ratio is checked. RNA is considered pure if the O.D ratio is between 1.8 and 2.0.

\section{RNA efficiency test}

Before performing the RT PCR-Array, the RNA samples are tested for the efficiency of the reverse transcription to produce the cDNA on the RNA samples (Figure 1) using $1.0 \mu \mathrm{g}$ of random primer, PCR components and master mixture (Promega USA).

\section{Real time- PCR array}

Real time-PCR array were performed to quantitate human cytokine and chemokine mRNA levels expression levels of 84 different cytokines and chemokines in control's leukocytes concentrate. Isolated cDNA were synthesized using SABioscince kit. Each cDNA sample was added to RT-qPCR master Mix containing SYBR Green and reference dye (SABioscince). Twenty five $\mu \mathrm{L}$ of cDNA-Master Mix mixture was added to each well across the PCRarrays. PCR-arrays contain 12 internal gene controls (SABioscince).

Thermocycling conditions were $95^{\circ} \mathrm{C}$ for 10 min and 40 cycles of $\left(95^{\circ} \mathrm{C}\right.$ for 15 $\mathrm{sec}, 60{ }^{\circ} \mathrm{C}$ for $1 \mathrm{~min}$ ) using Bio-RadiCycler real-time PCR detection systems.

\section{Real-Time PCR detection}

The threshold cycle values (Ct values) are calculated for each well using iQ 
cycler Bio-Rad software-USA. Acute Ct values from different previous studies were calculated according to standard gene expression data (Al-Ghazal, 2010). The data is exported to a blank Excel Spread-sheet for use with SABioscience Data Analysis Template Excel File. Melting curve program (cycle 1, 1 repeat, $95 \mathrm{C}$ for $1 \mathrm{~min}$. cycle 2,1 repeat, $55 \mathrm{C}$ for $1 \mathrm{~min}$. cycle 3,80 repeat, $55 \mathrm{C}$ for $10 \mathrm{sec}$.) is run immediately after the cycling program, and generates a first derivative dissociation curve for each well in the entire plate. The fold-change is calculated for each gene in control and acute groups as $2^{\wedge}(-\Delta \Delta \mathrm{Ct})$.

\section{Acute samples}

\section{Gene-Data Collection}

Up regulated immune-inflammatory genes were collected from previous

\begin{tabular}{|c|c|c|c|c|c|c|c|c|c|c|c|c|}
\hline $\begin{array}{l}\text { Layou } \\
\mathrm{t}\end{array}$ & 01 & 02 & 03 & 04 & 05 & 06 & 07 & 08 & 09 & 10 & 11 & 12 \\
\hline $\mathbf{E}$ & $\begin{array}{l}\text { CARD18 } \\
\mathbf{1 . 0 7} \\
\text { C }\end{array}$ & $\begin{array}{l}\text { IFNA2 } \\
\mathbf{1 1 . 2 7} \\
\text { OKAY }\end{array}$ & $\begin{array}{l}\text { IL10 } \\
\mathbf{1 0 3 . 5 8} \\
\text { OKAY }\end{array}$ & $\begin{array}{l}\text { IL10RA } \\
\mathbf{1 2 . 0 8} \\
\text { OKAY }\end{array}$ & $\begin{array}{l}\text { IL10RB } \\
\mathbf{1 . 0 7} \\
\text { C }\end{array}$ & $\begin{array}{l}\text { IL13 } \\
1.07 \\
\text { C }\end{array}$ & $\begin{array}{l}\text { IL13RA1 } \\
\mathbf{1 . 0 7} \\
\text { C }\end{array}$ & $\begin{array}{l}\text { IL17C } \\
\mathbf{1 . 0 7} \\
\text { C }\end{array}$ & $\begin{array}{l}\text { IL1A } \\
\mathbf{1 . 0 7} \\
\text { C }\end{array}$ & $\begin{array}{l}\text { IL1B } \\
\mathbf{1 . 0 7} \\
\text { C }\end{array}$ & $\begin{array}{l}\text { IL1F10 } \\
\mathbf{1 . 0 7} \\
\text { C }\end{array}$ & $\begin{array}{l}\text { IL36RN } \\
\mathbf{1 . 0 7} \\
\text { C }\end{array}$ \\
\hline $\mathbf{F}$ & $\begin{array}{l}\text { IL36A } \\
\mathbf{1 . 0 7} \\
\text { C }\end{array}$ & $\begin{array}{l}\text { IL37 } \\
\mathbf{1 . 0 7} \\
\text { C }\end{array}$ & $\begin{array}{l}\text { IL36B } \\
\mathbf{1 . 0 7} \\
\text { C }\end{array}$ & $\begin{array}{l}\text { IL36G } \\
\mathbf{1 . 0 7} \\
\text { C }\end{array}$ & $\begin{array}{l}\text { IL1R1 } \\
\mathbf{1 . 0 7} \\
\text { C }\end{array}$ & $\begin{array}{l}\text { IL1RN } \\
\mathbf{1 . 0 7} \\
\text { C }\end{array}$ & $\begin{array}{l}\text { IL22 } \\
\mathbf{1 . 0 7} \\
\text { C }\end{array}$ & $\begin{array}{l}\text { IL5 } \\
\mathbf{1 . 0 7} \\
\text { C }\end{array}$ & $\begin{array}{l}\text { IL5RA } \\
\mathbf{1 . 0 7} \\
\text { C }\end{array}$ & $\begin{array}{l}\text { CXCL8 } \\
\mathbf{3 4 . 1 7} \\
\text { OKAY }\end{array}$ & $\begin{array}{l}\text { CXCR1 } \\
\mathbf{1 . 0 7} \\
\text { C }\end{array}$ & $\begin{array}{l}\text { CXCR2 } \\
\mathbf{1 . 0 7} \\
\mathrm{C}\end{array}$ \\
\hline G & $\begin{array}{l}\text { IL9 } \\
\mathbf{1 . 0 7} \\
\text { C }\end{array}$ & $\begin{array}{l}\text { IL9R } \\
\mathbf{1 . 0 7} \\
\mathrm{C}\end{array}$ & $\begin{array}{l}\text { LTA } \\
\mathbf{1 . 0 7} \\
\text { C }\end{array}$ & $\begin{array}{l}\text { LTB } \\
\mathbf{1 . 0 7} \\
\text { C }\end{array}$ & $\begin{array}{l}\text { LTB4R } \\
\mathbf{1 . 0 7} \\
\text { C }\end{array}$ & $\begin{array}{l}\text { MIF } \\
\mathbf{1 . 0 7} \\
\text { C }\end{array}$ & $\begin{array}{l}\text { AIMP1 } \\
\mathbf{1 . 0 7} \\
\text { C }\end{array}$ & $\begin{array}{l}\text { SPP1 } \\
\mathbf{1 . 0 7} \\
\text { C }\end{array}$ & $\begin{array}{l}\text { TNF } \\
\mathbf{1 . 0 7} \\
\text { C }\end{array}$ & $\begin{array}{l}\text { CD40LG } \\
\mathbf{1 . 0 7} \\
\text { C }\end{array}$ & $\begin{array}{l}\text { TOLLIP } \\
\mathbf{1 . 0 7} \\
\mathrm{C}\end{array}$ & $\begin{array}{l}\text { XCR1 } \\
\mathbf{1 . 0 7} \\
\text { C }\end{array}$ \\
\hline
\end{tabular}

The features of gene Array used in gene expression analysis were arranged in studies after infection with HIV. The collected genes that their gene expression changes (with different fold change) were regarded as the acute sample. The fold changes of genes samples were changed into threshold values $(\mathrm{Ct})$ which represent the initial cycle at which the DNA sample was amplified using Real Time PCR-ArrayData Analysis according to standard tables (Al-Ghazal, 2010)

\section{$\underline{\text { Results and Discussion }}$}

The total Gene expression analysis results of the four selected genes were collected from Real time PCR Array analysis (table1).

Table1: Real time PCR Array analysis, last part of PCR array illustrates four up regulated genes with red color out of 84 immuno-inflammatory genes. 
specific Template which showed position, symbol and value of fold change for each gene(Table 2).

Table 2: Position, symbol, and fold change (in red color) of immune-

\begin{tabular}{|l|l|r|c|}
\hline \multicolumn{5}{|l|}{ Real time PCR Array tray } & Fold Change & Comments \\
\hline Position & Symbol & 1.0678 & C \\
\hline E01 & CARD18 & $\mathbf{1 1 . 2 7 1 3}$ & OKAY \\
\hline E02 & IFNA2 & $\mathbf{1 0 3 . 5 7 8 6}$ & OKAY \\
\hline E03 & IL10 & $\mathbf{1 2 . 0 8 0 3}$ & OKAY \\
\hline E04 & IL10RA & 1.0678 & C \\
\hline E05 & IL10RB & $\mathbf{3 4 . 1 6 8 2}$ & OKAY \\
\hline F10 & CXCL8 & 1.0678 & C \\
\hline F11 & CXCR1 & 1.0678 & C \\
\hline F12 & CXCR2 & 1.1444 & OKAY \\
\hline Housekeeping genes control (H1-H5) and Control genes (H6-H12) & 0.9295 & OKAY \\
\hline H01 & B2M & 0.9963 & OKAY \\
\hline H02 & HPRT1 & 0.9295 & OKAY \\
\hline H03 & RPL13A & 0.9295 & OKAY \\
\hline H04 & GAPDH & 1.0678 & OKAY \\
\hline H05 & ACTB & 0.8673 & OKAY \\
\hline H06 & HGDC & 0.9963 & OKAY \\
\hline H07 & RTC & 1.0678 & OKAY \\
\hline H08 & RTC & 0.7045 & OKAY \\
\hline H09 & RTC & 1.51 & OKAY \\
\hline H10 & PPC & 0.9295 & OKAY \\
\hline H11 & PPC & & \\
\hline H12 & PPC & \multicolumn{3}{|c|}{} \\
\hline
\end{tabular}

The fold changes of the four inflammatory genes were arranged in table 3 and their $\mathrm{Ct}$ values were calculated using standard tables.

Table 3: Fold change of affected genes from three replicaofreferencesand Ctvalues for acute and control samples.

\begin{tabular}{|l|l|l|l|l|}
\hline Number of gene & 1 & 2 & 3 & 4 \\
\hline $\begin{array}{l}\text { Gene position in } \\
\text { Macro- array }\end{array}$ & E02 & E03 & E04 & F10 \\
\hline $\begin{array}{l}\text { Gene symbolin } \\
\text { Macro- array }\end{array}$ & IFNA2 & IL-10 & IL10RA & CXCL8 \\
\hline Fold change 1 & $\mathbf{2}$ & $\mathbf{2}$ & $\mathbf{2}$ & $\mathbf{2}$ \\
\hline CtControl & 30.5 & 30.5 & 30.5 & 30.5 \\
\hline
\end{tabular}


AL-Qadisiyah Journal of pure Science Vol.23 No. 1 Year 2018

\begin{tabular}{|l|l|l|l|l|}
\hline Ct Acute & 27.8 & 27.8 & 27.8 & 27.8 \\
\hline Fold change 2 & $\mathbf{4 . 8}$ & $\mathbf{4 . 6}$ & $\mathbf{1 3 . 0}$ & $\mathbf{2 . 5}$ \\
\hline Ct Control & 28.9 & 27 & 33.6 & 27.7 \\
\hline Ct Acute & 23.4 & 21.3 & 28.2 & 21.8 \\
\hline Fold change 3 & $\mathbf{8 . 9}$ & $\mathbf{6 . 0}$ & $\mathbf{2 4}$ & $\mathbf{2 . 1}$ \\
\hline Ct Control & 23.2 & 23.7 & 24.0 & 24.4 \\
\hline Ct Acute & 27.6 & 29.6 & 29.0 & 28.8 \\
\hline
\end{tabular}

The mean of fold changes of the four genes subjected to study were calculated according to standard tables determined and their new $\mathrm{Ct}$ values were (Table 4)

Table 4: Features of Immune-inflammatory genes in array and their control and acute $\mathrm{Ct}$ values.

\begin{tabular}{|l|l|l|l|l|l|l|}
\hline $\begin{array}{l}\text { Gene } \\
\text { number }\end{array}$ & $\begin{array}{l}\text { Gene } \\
\text { Position } \\
\text { in Macro } \\
\text { array }\end{array}$ & Gene name & $\begin{array}{l}\text { Gene } \\
\text { Symbol }\end{array}$ & $\begin{array}{l}\text { Mean of } \\
\text { fold } \\
\text { change }\end{array}$ & $\begin{array}{l}\text { Ct value } \\
\text { Control }\end{array}$ & $\begin{array}{l}\text { Ct } \\
\text { value } \\
\text { Acute }\end{array}$ \\
\hline 1 & E02 & $\begin{array}{l}\text { Interferon, } \\
\text { alpha 2 } \\
\text { (Kerr } \text { et } \\
\text { al,2008) }\end{array}$ & IFNA2 & $\mathbf{5 . 2 3}$ & $\mathbf{2 4 . 5}$ & $\mathbf{2 1 . 0}$ \\
\hline 2 & E03 & $\begin{array}{l}\text { Interleukin 10 } \\
\text { (Gupta, and } \\
\text { Rao, 2011) }\end{array}$ & IL-10 & $\mathbf{4 . 2}$ & $\mathbf{2 8 . 7}$ & $\mathbf{2 2 . 1}$ \\
\hline 3 & $\begin{array}{l}\text { Interleukin 10 } \\
\text { receptor, alpha } \\
\text { (Lian } \text { et } \\
\text { al,2012) }\end{array}$ & IL10RA & $\mathbf{1 3}$ & $\mathbf{2 4 . 5}$ & $\mathbf{2 1 . 0}$ \\
\hline 4 & F10 & $\begin{array}{l}\text { chemokine } \\
\text { (C-X-C motif) } \\
\text { ligand } 8 \\
\text { (Qiu } \text { et al }, \\
\text { 2007) }\end{array}$ & CXCL8 & $\mathbf{2 . 2}$ & $\mathbf{2 7 . 0}$ & $\mathbf{2 2 . 0}$ \\
\hline
\end{tabular}


From Real time PCR Arrayanalysis, important results were collected. The results showed that all subjected genes were up regulated with different fold change (Figure1) for each gene (IFNA2, 11.2713 fold; IL10, 103.5786 fold; IL10RA2, 12.0803fold; CXCL8, 34.1682 fold) (figure 1 and 2)
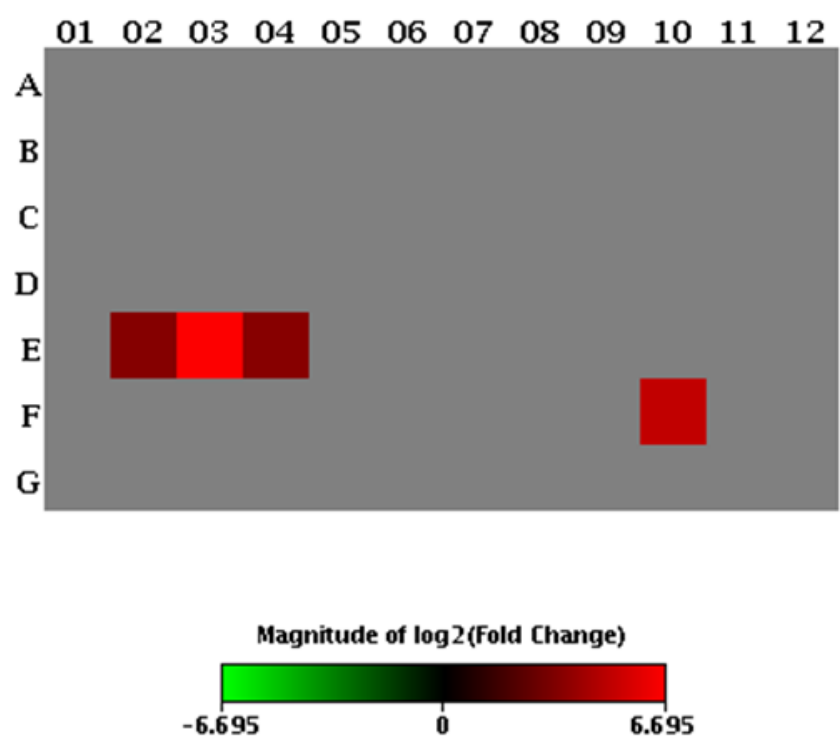

Figure 1: Gene-Heat Map: Upregulated genes (Red color) after infection with HIV. From scatter plot,(Figure 2) it is clear that the four genes vary in their ability to stimulate the frequency of mRNA transcript, this variation is may be due to the variation of the specific function or roll for each gene. 


\section{AL-Qadisiyah Journal of pure Science Vol.23 No. 1 Year 2018}

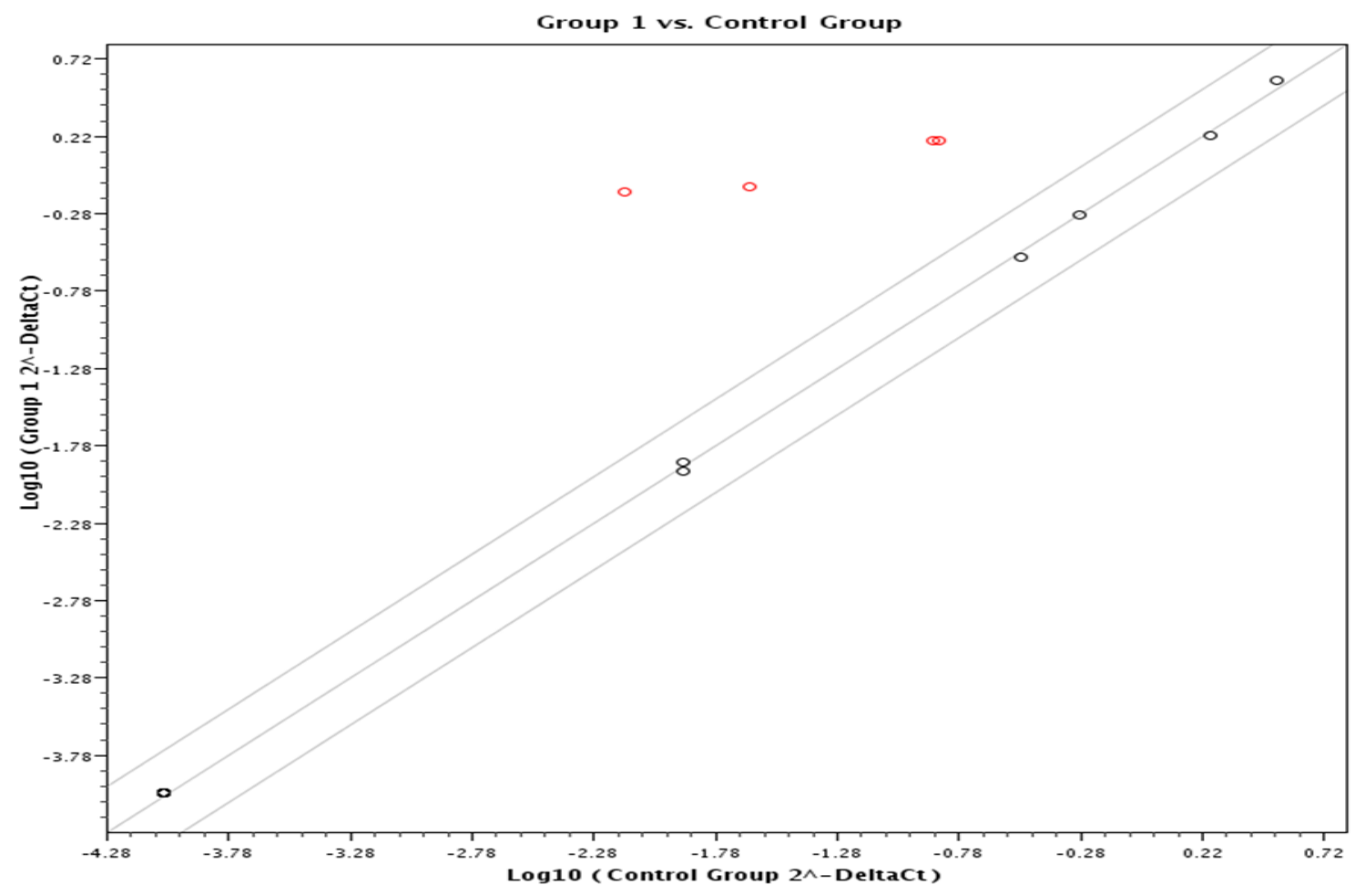

Figure 2: Scatter plot - Genes: Upregulated genes(red color) after infection with HIV

Interferon alpha 2 upregulated with 11.2713 fold(Figure3). IFNA2 acts as signaling protein produced by the cells of the immune system and regard as a key indicator of viral infection (Kotenkoet al., 2003).Many studies showed agreement with the result of this study such as Huang et al., 2010 which recorded that infection with virus stimulates the upregulation of IFN and give a protective role against viral infections. Interferon production also increased significantly in most vertebrates after the infection of virus (Dillon, and Runstadler, 2010).Interferon alpha 2 is highly upregulated in viral infections and stimulates gene expression in natural killercells and antigen processing induces hundreds of interferon stimulating genes (ISGs) which activate antiviral state in the infected cells (Matikainenet al., 2001; Dalodet al., 2002; Sato et al., 2000).

Viral infection stimulates the upregulation of IENA2 gene which degrades the mRNA in host cell and blocks the spreading of viral infection in the body, sometimes at the expense of accelerating the death of the infected cells. When interferonis released by infected cells it induces an antiviral state in surrounding uninfected cells, thereby making itdifficult for virus to spread from the initial foci of infection (Andrejeva et al., 2002). The effect of viral infection on IFNA2stimulates upregulation of interferon, alpha 2-mRNA which in turn induces several antiviral proteins, 
including protein kinase $\mathrm{R}$ (PKR) and oligo-adenylate synthetases (OAS). The activation of PKR leads to general inhibition of protein synthesis and replication of the invader virus. OAS activation leads to degradation of host cell mRNAs and viral RNA (Bone et al., 2005). Other studies showed that viral infection to human cells induces the expression of IFN type 1 with high significance (Kahlet al., 2010; Hutnicket al., 2010).

Interleukin-10 (IL10) cytokine upregulated with 103.5786 fold (figure 3 ). This upregulation may be induced by the invading virus to activate antiinflammatory function and to provide a safe environment for viral replication. IL10 represses the expression of TNF- $\alpha$, IL6 and IL1 by activating macrophages.
Other study reported that IL10 appears to play a detrimental role during host response to acute viral infection (Keeret al., 2008).In agreement with this researchanother study showed a significant increase in IL10 mRNA expression after virus infection and accompanied with acute asthma (Grissellet al., 2005).

Previous studies showed that viral infection also stimulates high expression of Interleukine-10 and activates signal transducer activity to stimulate growth factor binding and cytokine binding (Sieget al., 1996; De Waal et al., 1991).

Another published work revealed a wide involvement of interleukin 10 to prevent viral infections and produce regulatory cells that are involved in protection against allergic diseases (Megeet al., 2006).

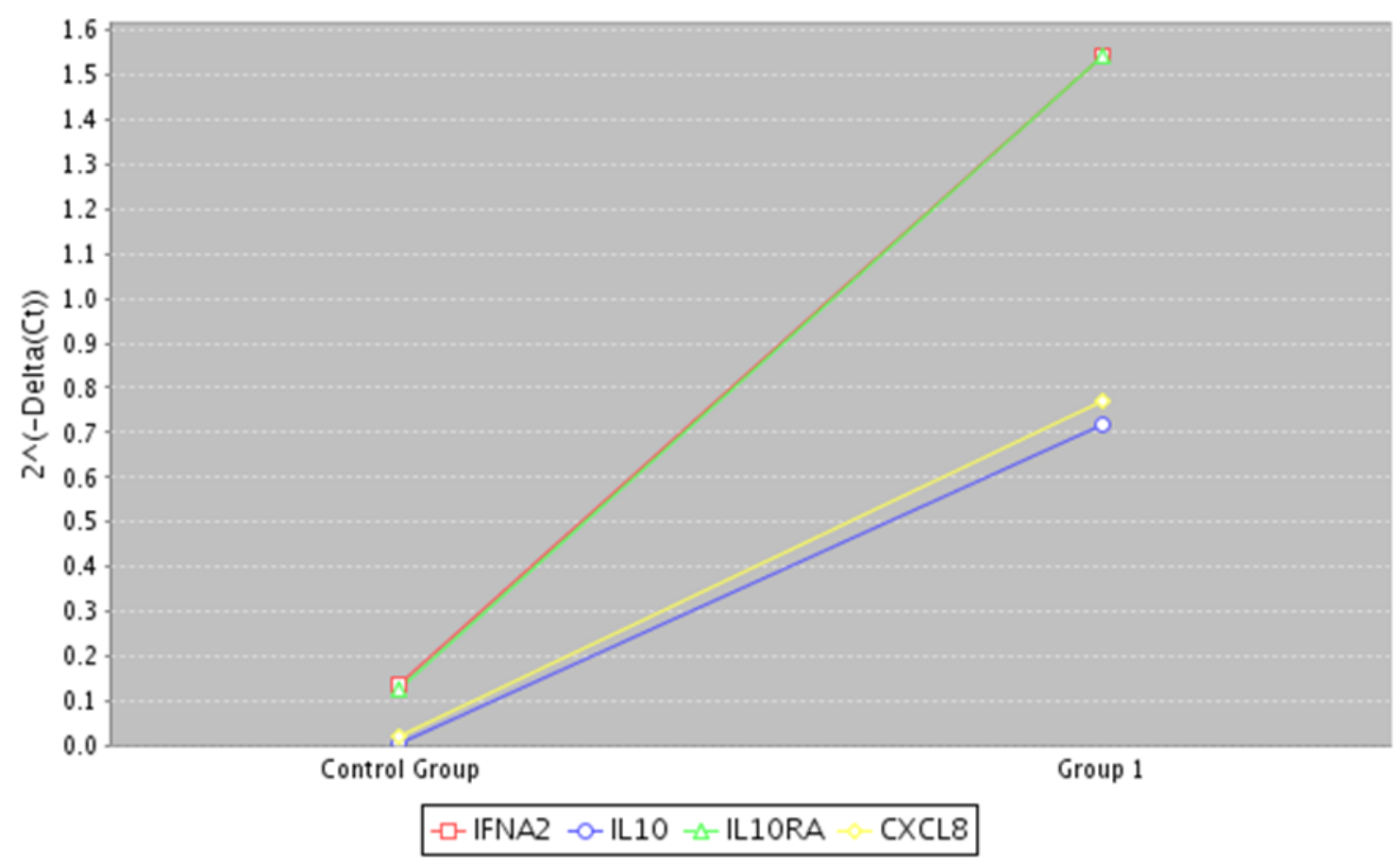

Figure 3: Gene-curves: Upregulated genes after infection with HIV 
Interleukin 10 receptor, alpha (IL10RA) up regulated with 12.0803 fold in this study (Figure 4). This cytokine act as receptor for IL10 cytokines, it is reported that it activates and promotes survival of progenitor myeloid cells through viral infection. Activation of this receptor leads to tyrosine phosphorylation of JAK1 and TYK2 kinases during microbial infection. Previous study showed upregulation of IL10RA in patient with hepatitis C infection, and multiple sclerosis (Kerr et al, 2008).In another study, IL10RAGene was up regulated with relative expression levels $\geq 2$ fold after infection with neuroinvasive viruses like West Nile virus.

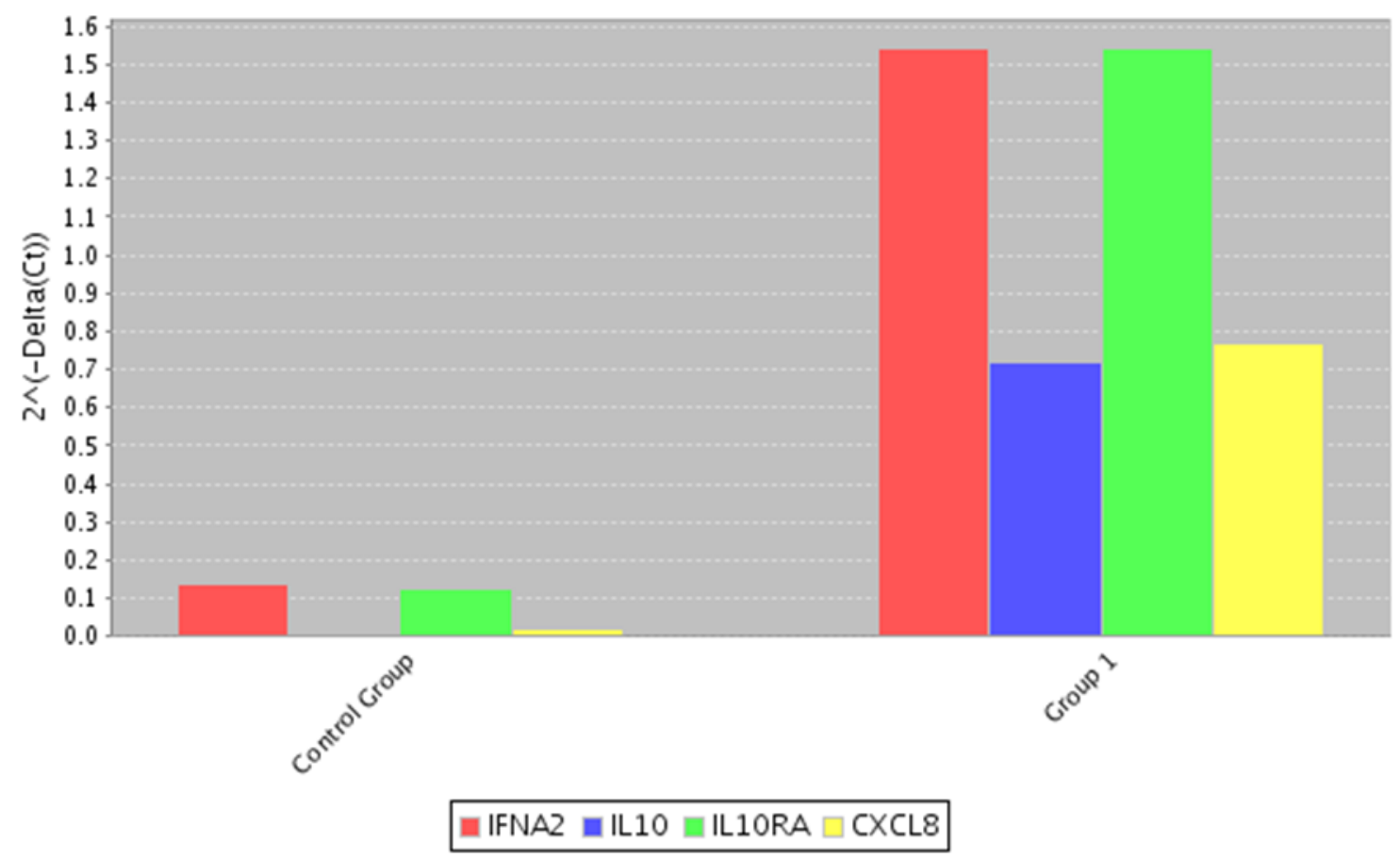

Figure 4: Gene-Histogram: Upregulated genes after infection with HIV

CXCL8 gene is up regulated with 34.1682 fold (Figur 4). This chemokine is one of the major mediators of the viral inflammatory response. The protein of this gene acts as chemo-attractant and is secreted by several cell types. Previous study revealed that this gene is believed to play a role in the pathogenesis of bronchiolitis, a common respiratory tract disease caused by viral infection (Qiu $e t$ $a l$, 2003). In disagreement to this study an old study referred that CXCL8 productionis suppressed in human monocytes infected with viruses (Hofmann et al., 1997). Other studies recorded that this gene was upregulated during viral infection because it acts as proinflammatory gene against viral infection especially rhinovirus infection (Lund et al,2003; Qiu et al, 2007). 


\section{Conclusion and recommendation}

In conclusion, the results of this study revealed that:

The generation of RT-PCR-Array allows the comparison of different viruses with respect to their impact on cellular gene expression.Clear differences were found in the four human gene expression induced by HIV. These differences may be due to the differences in the function of each gene. The information obtained from this study will enhance our view of HIV infections and its influence on host cell biology and may eventually lead to new therapeutic targets.

\section{Reference}

AL-Ghazal, A. T. (2010). Effect of viral respiratory infections by influenza $A$ virus, Parainfluenza viruses and Adenoviruses on Immuno-inflammatory gene expression /inhibitory of human white blood cells.Ph.D thesis. University of Jordan, Amman,Jordan, 179-190.

Andrejeva, J., Young, D., Goodbourn, S., and Randall, R. (2002). Degradation of STAT1 and STAT2 by the V proteins of simian virus 5 and human parainfluenza virus type 2 , respectively: consequences for virus replication in the presence of alpha/beta and gamma interferons, Journal of Virology, 76, 2159-2167.

Bone, S., Tang K., Vincent, C., Cheng, P., Susanna K., Clarence C., Tsun-leung C., Alan K., Ivan F., Suet-yi L., and Kwok-yung Y. (2005). Comparative host gene transcription by micro- array
A complete analysis of changes in cellular functions including the production of gene products and proteinprotein interactions within the stimulated cells will be required to explore the underlying mechanism of the effects of HIV infection during the course of infection.

Further studies using reverse genetics are required to identify viral genes that are critical for the differential upregulation or down-regulation of host genes.

analysis early after infection of the Huh7 cell line by severe acute respiratory syndrome coronavirus and human coronavirus 229E, Journal of Virology, 79, 6180-6193.

Campeau, P., Rafei, M., Boivin, M., Sun, Y., Grabowski, G., Galipeau, J. (2009). Characterization of Gaucher disease bone marrow mesenchymal stromal cells reveals an altered inflammatory secretome, Blood, 114(15). 3181-3190.

Clewley J. (2004). A role for arrays in clinical virology: fact or fiction, Journal of Clinical Virology, 29, 2-12.

Dalod, M., Salazar-Mather, T., Malmgaard, L., Lewis, C., AsselinPaturel, C., Briere F., Trinchieri, G, and Biron, C. (2002). Interferon alpha/beta and interleukin 12 responses to viral infections: pathways regulating dendritic cell cytokine expression in vivo, Journal 
of Experimental Medicine, 195: 517523.

David, F., Farley, J., Huang, H., Lavoie, J., Laverty, S., (2008). Cytokine and chemokine gene expression of IL-1beta stimulated equine articular chondrocytes, Veterinary Surgry, 37 (5). 499 .

De Waal M., Haanen, J., Spits, H., Roncarolo, M., TeVelde, A., Figdor, C., Johnson, K., Kastelein, R., Yssel, H., and De Vries, J. (1991). Interleukin 10 (IL-10) and viral IL-10 strongly reduce Ag-specific human $\mathrm{T}$ cell proliferation by diminishing the antigenpresenting capacity of monocytes via downregulation of class II major histocompatibility complex expression, Journal of Experimental Medicine, 174, 915.

Dillon D., and Runstadler J. (2010). Mx gene diversity and influenza association among five wild dabbling duck species (Anas spp.) inAlaska, Infection, Genetics and Evolution, 796, 1-8.

Gupta, N. and Rao, P.(2011).

Transcriptomic profile of host response in Japanese encephalitis virus infection. Virology journal, 20, 11,9. (about fold chang of IL10)

Grissell T., Heather P., Darren R., Michael J. Boyle, M., Peter D., Bruce F. and Peter G. (2005). Interleukin-10 gene expression in acute virus-induced asthma, American Journal of Respiratory and Critical Care Medicine, 172, 433-439.

Hofmann P, Sprenger H., Kaufmann A., Bender A., Hasse C., Nain M. and
Gemsa D. (1997). Susceptibility of mononuclear phagocytes to influenza A virus infection and possible role in the antiviral response, Journal of Leukocyte Biology, 61, 408-414.

Huang H., Li H., Zhou P., and Ju D. (2010). Protective effects of recombinant human granulocyte macrophage colony stimulating factor on H1N1 influenza virus-induced pneumonia in mice, Cytokine, 51, 2, 151-157.

Kerr JR, Burke. B., Petty R., Gough, D., and Fear D. (2008). seven genomic subtypes of chronic fatigue syndrome/myalgic encephalomyelitis: a detailed analysis of gene networks and clinical phenotypes. Journal of Clinical jcp.bmj. (about fold chang of IFNA2).

Keer S., Luisa T., and Dennis W. (2008). A detrimental Role for IL-10 During HostImmune Responses to Influenza Virus Infection, FASEB J, 22: 857.

Khatri M, Brien T., Goyal S., and Sharma J. (2010) Isolation and characterization of chicken lung mesenchymal stromal cells andtheir susceptibility to avian influenza virus, Developmental and Comparative Immunology, 34, 474-479.

Kotenko S., Gallagher G., Baurin V., Lewis-Antes A., Shen M, Shah N., Langer J., Sheikh F., Dickensheets H., and Donnelly R., (2003). IFN-lambdas mediate antiviral protection through a distinct class II cytokine receptor complex, Nature Immunology, 4, 69-75.

Lian, L. Lian,LQu,U Sun HY, Chen, YM Lamont SJ. (2012) Gene expression 
analysis of host spleen responses to Marek's disease virus infection at late tumor transformation phase, Virology , 12:4.

LundB., Ashikian,N., Ta, H., Chakryan Y. (2004)Increased CXCL8 (IL-8) expression in multiple sclerosis. Journal of Virology. 5:14.

Matikainen, S., Paananen, A. Miettinen, M., Kurimoto, M.,Timonen, T., Julkunen, I., and Sareneva. T. (2001). IFN-alpha and IL-18 synergistically enhance IFN-gamma productionin human NK cells: differential regulation of Stat 4 activation and IFN-gamma geneexpression by IFN-alpha and IL-12, European Journal of Immunology, 31, 2236.

Mege J., Soraya M., Amelie H., Christian C., and Didier R. (2006). The two faces of interleukin 10 in human infectious diseases, The Lancet Infectious Diseases, 6 (9). 557-569. Myskiw C, Arsenio J, van Bruggen R, Deschambault Y, Cao J. (2009). Vaccinia virus E3 suppresses expression of diverse cytokines through inhibition. Journal of Virology, 83(13):6757-68.

Penelope A., Bryant D., Roy R., and Nigel C. (2004). Chips with everything: NA microarrays infectious diseases, Lancet Infectious Diseases, 4, 100-111.
Qiu,Y., Zhu,J, Bandi,V. Atmar, R. (2003) Biopsy neutrophilia, neutrophil chemokine and receptor gene expression in severe exacerbations of chronic obstructive pulmonary disease.

American journal of Med. App.4: 22.

Qiu,Y J Zhu, V Bandi, KK Guntupalli, PK Jeffery (2007).Bronchial mucosal inflammation and upregulation of CXC chemoattractants and receptors in severe exacerbations of asthma. Microbiology, 15:9.

Sato M, Suemori H, Hata N, (2000).

Distinct and essential roles of transcription factors IRF-3 and IRF-7 in response to viruses for IFNalpha/ beta gene induction, Immunity, 13, 539-548.

See H., and Wark P., (2008). Innate immune response to viral infection of the lungs, Paediatric Respiratory Reviews, 9, 243-250.

Sieg S., King C., Huang Y., and Kaplan D., (1996). The role of interleukin-10 in the inhibition of T-cell proliferation and apoptosis mediated by parainfluenza virus type 3, Journal of Virology, 70, 4845.

Simpson J., Scott R., Boyle M., and Gibson G. (2006). Inflammatory subtypes in asthma: assessment and identification using induced sputum, Respirology, 11, 54-61. 